\title{
The Role of the Notary/PPAT in Process Transfer of Land Functions From Agricultural Land Into Non-Agricultural Land in Demak District Land Office
}

\author{
Budi Santosa', Muslich Ashari ${ }^{2}$ and Amin Purnawan ${ }^{3}$
}

Abstract. The purpose of this study is as follows: 1) To determine the role of the Notary PPAT in the process of the transfer function of soil from agricultural to nonagricultural land in the District Land Office Demak.2) To know the obstacles in the process of soil functions from agriculture to non-agricultural land in the Land Office District Demak.3) .To find out a solution to the obstacles in the process of the transfer function of soil from agricultural to non-agricultural land in Demak District land Office.

Methods using sociological juridical approach, Research Specs, Types and Sources of Data, Data Collection Methods, Technical Analysis.

Based on the results of the study concluded that the procedure of land transfer function of agriculture to non-agricultural land in the National Land Office Demak, do the applicant by way of location permits, licenses and land use permits land use changes. Factors to be an obstacle in the procedure of the transfer function of the land from agricultural land to non-agricultural in the Office of the National Land Demak and how to overcome among others: the permissions that are not in accordance with the plan of spatial Demak, settlement efforts in addressing licensing should be transparent and in accordance with the regional spatial plan Demak. Suggestions Should the Office of the National Land Demak apply policy rules corresponding spatial Demak district in order to avoid the equalizing impact of underdevelopment in the region of Demak, therefore the application mechanism location permits, permit the use of land and permission changes in land use were tightened in order transition of agricultural land into non-agricultural destructive to the environment of Demak.

Keywords: Notary / PPAT, Transfer of Functions Land, Agricultural Land to NonAgricultural.

\section{Introduction}

The importance of soil for human life because human life cannot be separated entirely from the ground. Humans live on the land and obtain food by way of utilizing land. Historical development or destruction is determined also by land. Problems of land can lead to disputes caused devastating human beings want to dominate other people's land for resources-natural resources contained therein. Man will live happy all-sufficient if they can use controlled or owned land in accordance with the applicable laws of nature. Humans can live in peace and peace if they can use the rights and obligations in accordance with the limit - certain extent in the applicable law governing human life in society. ${ }^{4}$

\footnotetext{
${ }^{1}$ Students of Master of Notarial Law, Faculty of Law, Universitas Islam Sultan Agung and Notary Office staff and PPAT Djonny PRIATKO, SH, Mkn email: catharinafara@gmail.com

2 Students of Master of Law, Faculty of Law, Universitas Islam Sultan Agung email muslichashari30@gmail.com

${ }^{3}$ Faculty of Law, Universitas Islam Sultan Agung

${ }^{4}$ G. Kartasapoetra dkk, Hukum Tanah Jaminan UUPA bagi Keberhasilan Pendayagunaan Tanah,

(Jakarta : Rineka Cipta, 2002), p.1
} 
The existence of a law or regulation to regulate the human need for land to avoid disputes, acts of ill - treatment and the duality of ownership to a land. On 26 September 1960 enacted Act-Agrarian Law, better known by the entry into BAL, fundamental changes in the Basic Agrarian Law in Indonesia, especially in the area of land law called the Law of the Land, while among government and commonly known as the Agrarian Law. Entry into force of the BAL indirectly remove the eigendom rights, as well as rights- other land rights are not appropriate. ${ }^{5}$

The provisions of the Indonesian government under Article 6 of Act No. 5 of 1960 on Basic Regulation of Agrarian Principles, which states that "All rights to the land has a social function."

Their population growth and the development of ever-increasing impact on land use changes. Changes in land use will result in a shift in the function of soil from agricultural land to non-agricultural. Agricultural land in general is all the land that became the right person, in addition to land for residential and enterprise. Farmland is all farmland, ponds for fishing, the land where the livestock, land fallow thickets and forest where livelihood to those who are entitled. Therefore we need a regulation to control the change of use of agricultural land to non-agricultural namely the Government Regulation No. 16 of 2004 on Land Stewardship.

\section{Research methods}

Metode approach used in this study is a sociological juridical methods. Specifications of this study is a descriptive analysis, the method of research to give an overview of the situation or event and explain the relationship between these events with problems to be studied. The results of this study are expected to provide a clear picture of the role of the Notary PPAT in the process of the transfer function of soil from agricultural to non-agricultural land in Demak District Land Office.

The data analysis was conducted using qualitative descriptive approach, the qualitative approach is not used statistical parameters in order to analyze the data. The data collected in the field research is the primary data derived from interviews or interviews with the subjects (parties) in the study, who is the subject of this study Notary or PPAT in Demak and Kasubsie Public Land Office Demak relating to the cases in the study this. How interpretation above is useful to find a principle or rule of law.

\section{Results and Discussion}

2.1. The role of the Notary / PPAT In Process Transfer of Functions From Agricultural Land Into Non-Agricultural Land In Demak District Land Office.

Notaries in running the office should heed the various laws that apply. Although in carrying out his set in a special regulation (UUJN), appointment and dismissal by the government in this case the Ministry of Justice, took the oath and so forth. Notaries do not receive a salary and / or pension from the government, but to receive an honorarium from the applicant as remuneration, in accordance with the applicable regulations.

Based UUJN declared 2014 the notary is a public official who is authorized to make an authentic deed and other authorities. Notary Deed is an authentic deed made by or before a Notary according to the forms and procedures stipulated in the Law. As public

\footnotetext{
${ }^{5}$ Adrian Sutedi, Peralihan Hak Atas Tanah dan Pendaftarannya, (Jakarta : Sinar Grafika, 2008), p. 6
} 
officials, as well as members of the public, a notary cannot be separated from the life of society because society is constantly changing. Changes in society can affect the world Notary anyway. In running position, the Notary may affect applicant in determining the choice to determine their legal action.

Notary is a public official independent (standalone) are entitled to regulate, specify either office location and shape of the building and of the number and salaries of employees, does not depend on official and other institutions. Term "public" or general in the office of notary herein shall have the meanings these officials serve the public in terms of making a variety or a wide variety of authentic deeds related to the field of civil law that the authority has not been delegated to other officials and asked by the general public who need or interest that a legal act of their expressed in the form of an authentic deed and by law require in the form of an authentic deed.

Demak regency is a regency in Central Java which has a farm system that has been good. This is because in addition to the type of arable land for agriculture, the amount of agricultural land in the district is quite extensive. Even this district into a breadbasket for the region of Central Java in particular, to supply the surrounding area such as Semarang, Kudus, maybe even get to outside the province of Central Java. Therefore, the agricultural sector plays an important role for the reception of local revenue.

Based on the National Land Agency Regulation No. 2 of 2011 on Guidelines for Technical Considerations Land In Publishing License Location, Location Determination And Permission Change Land Use, land designated in the permit location of the land is according to spatial plan that is destined for use appropriate, that the land applied for license amendments, including former unproductive paddy fields so as not to influence public policy in the handling of food self-sufficiency and stability in its development does not cause nuisance / pollution of the surrounding environment.

In the case of use of agricultural land into non-agricultural land, it is necessary location permits, licenses and land use permits land use changes, which can be explained as follows: ${ }^{6}$

- Location permission

Location permit is a permit allotment of land use must be owned companies to acquire land needed for investment, which applies as transfer of license rights, and to use the land for purposes of the investment business, the breadth of the following restrictions:

- for agricultural $>25$ ha,

- for non-agricultural> $1 \mathrm{Ha}$.

- Land Utilization Permit

Land use permit is a permit allotment of land use must be owned private person or body that will carry out the activity or activities that result in changes in land use in buildings / work done, with the breadth of the following restrictions:

- for agricultural <= $25 \mathrm{Ha}$,

- for non-agricultural businesses $<=1 \mathrm{Ha}$,

- For activities in the field of social

- Land Use Change Permit

Land use change permit is a permit allotment of land use must have an individual who would change the designation of agricultural land into non-agricultural to residential homes personal/individual development, the broadest measure 5,000 m2

\footnotetext{
${ }^{6}$ Interview, Krisnawati, $\mathrm{SH}, \mathrm{MH}$, as Head of Regulation and Planning Land in Demak District Land Office, May 16, 2019
} 
(five thousand square meters). Gradually given per $600 \mathrm{~m} 2$ to over $600 \mathrm{~m} 2$ breadth with SKTBL.

Demak spatial arrangement is a form of equitable development in the region of Demak, in order to help the welfare of the people in the district of Demak.

In Demak conversion of agricultural land into non-agriculture has not become a threat monitor as in other areas, but as a regional food of the prohibition of land conversion is the government's priority to continue to maintain the productive land in Demak district in order to maintain food security." 7

Forms of surveillance and enforcement activities realized in the form of information activity report objectively about the utilization of space, whether appropriate or not in accordance with the spatial plan. A monitoring form is an attempt to observe, monitor and carefully check changes in spatial changes of agricultural land to non-agricultural land.

\subsection{Factors that become obstacles to diversion function Procedure Land of Agricultural Land to Non-Agricultural Land Offices Demak and how to overcome them.}

The transformation of land from agricultural to non-agricultural land in the implementation of experiencing various obstacles. This is due to public awareness is still lacking and due to local regulations are not strictly against the misuse of land.

The factors that become a bottleneck in the transfer procedure soil functions from agricultural to non-agricultural land is as follows: ${ }^{8}$

- Parties that permit conversion of agricultural land into non-agricultural land

During the terms and conditions set met then there is no obstacle to the District Land Office Demak as the licensor for issuing Land Use Change Permit.

- Law enforcement

If implemented correctly enforcement and firmness in the application of the law then change agriculture to non-agricultural land can be pressed optimally. So it does not violate spatial or development planning in Demak.

- Bureaucratic structure factors have an impact so great towards the implementation of changes in agricultural land into non-agricultural.

- Solutions to overcome obstacles in the process of transferring the function of soil from agricultural to non-agricultural land in Demak District Land Office, among others:

- Licensing factor which is not according to plan space Demak district, settlement efforts in addressing licensing should be transparent and in accordance with the regional spatial plan Demak.

- Factors that good law enforcement system that inhibits the function of the land transfer procedures, the efforts of law enforcement solution must be applied so that the government's policy and procedures for transferring optimal soil functions run in accordance with the spatial and town planning Demak district.

- Factors bureaucracy that the government's efforts in the dissemination of Regulation 19 of 2011 on Land Use Designation Permit, and other measures such as increasing the income of farmers for the implementation of this policy is going

\footnotetext{
7 Interviews, Krisnawati, $\mathrm{SH}, \mathrm{MH}$, as Head of Regulation and Planning Land in Demak District Land Office, May 16, 2019

${ }^{8}$ Interviews, Krisnawati, $\mathrm{SH}, \mathrm{MH}$, as Head of Regulation and Planning Land in Demak District Land Office, May 16, 2019
} 
Volume 6 Issue 2, June 2019

well. The fix: Application for change of agricultural land into non farming must comply with the rules of Regulation 19 of 2011 on Land Use Designation Permit.

\section{Closing}

\subsection{Conclution}

- Transfer procedures soil functions from agriculture to non-agricultural land in the National Land Office Demak, do the applicant by way of location permits, licenses and land use permits land use changes.

- Factors to be an obstacle in the procedure of the transfer function of the land from agricultural land to non-agricultural in the Office of the National Land Demak and how to overcome among others: the permissions that are not in accordance with the plan of spatial Demak, settlement efforts in addressing licensing should be transparent and in accordance with the regional spatial plan Demak

\subsection{Suggestions}

- Should the Office of the National Land Demak apply policy rules corresponding spatial Demak regency, in order to avoid the equalizing impact of underdevelopment in the region of Demak, therefore the application mechanism location permits, permit the use of land and permission changes in land use were tightened in order to shift the ground agriculture to non-agricultural destructive to the environment Demak.

- The need for integrated supervision between relevant agencies, namely the Land Office and District Demak, then minimized their misuse of land that may occur.

\section{Bibliography}

\section{Books}

[1] Kartasapoetra, G. dkk. Hukum Tanah Jaminan UUPA bagi Keberhasilan Pendayagunaan Tanah. Jakarta : Rineka Cipta, 2002

[2] Lestari, Dampak Konversi Lahan Pertanian Bagi Taraf Hidup Petani. Bogor : IPB, 2009

[3] Murniningtyas, Strategi Pengendalian Alih Fungsi Lahan Pertanian. Jakarta : Dirjen Pangan dan Pertanian, 2007

[4] Soemitro, Ronny Hanitijo. Metodologi Penelitian Hukum dan Jurimetri. Jakarta : Ghalia Indonesia, 2003

[5] Sutedi, Adrian. Peralihan Hak Atas Tanah dan Pendaftarannya. Jakarta : Sinar Grafika, 2008

[6] Wargakusuma, Hasan. Hukum Agraria I. Jakarta : Gramedia Pustaka Utama, 2005

\section{Legislation}

[1] Constitution of the Republic of Indonesia 1945

[2] Act No. 5 of 1960 on Basic Regulation of Agrarian. 
[3] Regulation of the Minister of Agriculture No. 81 Of 2013 on Technical Guidelines Procedures of Agricultural Land Transition Function

[4] Joint Instruction Minister of Home Affairs and Regional Autonomy with the Minister of Agrarian dated January 5, 1961 No. 01/09/12 sekra on Agricultural Land Notary law in 2014

\section{Articles / Internet}

[1] Martua Sihaloho, Arya Hadi Dharmawan dan Said Rusli, Konversi Lahan Pertanian dan Perubahan Agraria, Jurnal Solidality, 2007, Vol. 01 No. 2 